\title{
Purification and Characterization of an Acid Deoxyribonuclease from the Cultured Mycelia of Cordyceps sinensis
}

\author{
MaoQing Ye', Zheng Hu${ }^{\ddagger}$, , Ying Fan', Ling He ${ }^{\dagger}$, FuBao Xia and GuoLin Zou ${ }^{\dagger, *}$ \\ Department of Biochemistry, College of Life Sciences, Wuhan University, Wuhan 430072, P. R. China \\ ${ }^{\dagger}$ Hubei Province Key Laboratory of Industrial Microbiology, Hubei Polytechnic University, Wuhan 430068, P. R. China
}

Received 1 November 2003, Accepted 1 December 2003

\begin{abstract}
A new acid deoxyribonuclease (DNase) was purified from the cultured mycelia of Cordyceps sinensis, and designated CSDNase. CSDNase was purified by $\left(\mathrm{NH}_{4}\right)_{2} \mathrm{SO}_{4}$ precipitation, Sephacryl S-100 HR gel filtration, weak anion-exchange HPLC, and gel filtration HPLC. The protein was single-chained, with an apparent molecular mass of $\mathrm{ca}$. $34 \mathrm{kDa}$, as revealed by SDS-PAGE, and an isoelectric point of 7.05 , as estimated by isoelectric focusing. CSDNase acted on both double-stranded (ds) and single- stranded (ss) DNA, but preferentially on dsDNA. The optimum pH of CSDNase was pH 5.5 and its optimum temperature 55. The activity of CSDNase was not dependent on divalent cations, but its enzymic activity was inhibited by high concentration of the cation: $\mathrm{MgCl}_{2}$ above $150 \mathrm{mM}, \mathrm{MnCl}_{2}$ above $200 \mathrm{mM}, \mathrm{ZnCl}_{2}$ above $150 \mathrm{mM}$, $\mathrm{CaCl}_{2}$ above $200 \mathrm{mM}, \mathrm{NaCl}$ above $300 \mathrm{mM}$, and $\mathrm{KCl}$ above $300 \mathrm{mM}$. CSDNase was found to hydrolyze DNA, and to generate 3-phosphate and 5-OH termini. These results indicate that the nucleolytic properties of CSDNase are essentially the same as those of other wellcharacterized acid DNases, and that CSDNase is a member of the acid DNase family. To our knowledge, this is the first report of an acid DNase in a fungus.
\end{abstract}

Keywords: Acid DNase, Cordyceps sinensis, Endonuclease

\section{Introduction}

Deoxyribonucleases (DNases) occur in various organisms, including fungi (Conneely et al., 1976; Chen et al., 1993), and digest DNAs, though they have different requirements for

*To whom correspondence should be addressed.

Tel: +86-27-87645674; Fax: +86-27-87669560

E-mail: zouguolin@whu.edu.cn

${ }^{1}$ Co-corresponding author. cofactors, cations, and optional $\mathrm{pH}$ levels. DNases may be broadly divided into two classes, DNase I (EC 3.1.21.1) and DNase II (EC 3.1.22.1), based upon their $\mathrm{pH}$ optima and metal ion dependencies (Cunningham and Laskowski, 1953). The DNase II class, also named the Acid DNases, is a group of enzymes that cleaves DNA in a double-stranded fashion, with an acidic $\mathrm{pH}$ optimum, and have no requirement for divalent metal ions (Bernard, 1971). This is in contrast to the DNase I class members, which cleave DNA by nicking at near neutral $\mathrm{pHs}$, and which require divalent cations for full activity (Moore, 1981).

Acid DNases have been found in cells and are secreted by many organisms (Dulaney and Touster, 1972; Baker et al., 1998). The earliest identification of an acid DNase was recorded in 1947 (Catcheside and Holmes, 1947), and acid DNases were biochemically characterized in the $1960 \mathrm{~s}$ (Bernardi et al., 1965). Acid DNases have been implicated in many cellular processes. Former research considered acid DNase as a lysosomal enzyme that can be reversibly associated with the lysosomal membrane. Recent work has implicated this enzyme with lysosomal diseases and cancer, and in the apoptotic process (Barry and Eastman, 1993). Now, most research on acid DNase is focused on mammalian acid DNase, though a few researchers have concentrated on insect acid DNases. However, comparatively little research is aimed at understanding plant and microorganism acid DNases, which also have the potential to contribute to our understanding of the structure and of the biological functions of these DNases. Over the past few years several DNases have been found in fungi, such as Coprinus endonuclease from Coprinus cinereus (Lu et al., 1988; Kitamura et al., 1997), but no fungus acid DNA use has been characterized to date.

Cordyceps sinensis is a parasitic fungus that is of Lepidoptera larvae. For centuries, the fruiting bodies of $C$. sinensis have been used as both a food and a herbal tonic, named Dong-Chong-Xia-Cao in Mandarin China, and has been used to treat a variety of diseases. (SteinKraus and Whitfield, 1994; Zhu et al., 1998a, 1998b). In this report, we 
describe the purification and characterization of a new acid DNase cultured from mycelia of $C$. Sinensis. We conducted a comprehensive characterization of this enzyme, and compared it with several established acid DNases from mammal, insect and protozoan. We found that the isolated CSDNase was in fact a member of the acid DNases. To our knowledge, this is the first report of an acid DNase in a fungus.

\section{Materials and Methods}

Materials The Cordyceps sinensis (CCTCC AF99009) strain was obtained from China Center for Type Culture Collection (CCTCC). Sephacryl S-100 HR was purchased from Amersham Pharmacia Biotech (Uppsala, Sweden). All HPLC columns were purchased from Agilent Technologies (Palo Alto, USA). Porcine spleen DNase II, Crotalus adamanteus venom phosphodiesterase I, and bovine spleen phosphodiesterase II were purchased from Sigma (St. Louis, USA). Protein molecular weight marker was from Fermentas (Burlington, Canada). Chemicals used routinely were of analytical grade and of the highest purity.

Cultured Cordyceps sinensis $\quad C$. sinensis was first cultured on potato dextrose agar plates for $96 \mathrm{~h}$ at $28^{\circ} \mathrm{C}$. These starter cultures were then transferred to nutrient broth containing $(\mathrm{g} / \mathrm{L})$ : peptone 10 , glucose $30, \mathrm{~V}_{\mathrm{B} 1} 0.05, \mathrm{KH}_{2} \mathrm{PO}_{4} 1, \mathrm{MgSO}_{4} 0.2$, at $\mathrm{pH} 6.0$, on a rotary shaker at $120 \mathrm{rpm}$ for $96 \mathrm{~h}$ at $28^{\circ} \mathrm{C}$. The mycelia of $C$. sinensis were collected and stored at $-80^{\circ} \mathrm{C}$ (Hsu et al., 2002).

Purification of CSDNase Collected $C$. sinensis mycelia were fragmented using a Sonic Dismembrator in ice water, and extracted with extracting buffer ( $20 \mathrm{mM}$ Tris- $\mathrm{HCl}, 150 \mathrm{mM} \mathrm{NaCl}, 1 \mathrm{mM}$ DTT, $1 \mathrm{mM}$ EDTA, $0.5 \mathrm{mM}$ PMSF, pH7.0). After centrifugation, $\left(\mathrm{NH}_{4}\right)_{2} \mathrm{SO}_{4}$ was added to the supernatant to $20 \%$ saturation, and the mixture was allowed to stand for $4 \mathrm{~h}$ at $4^{\circ} \mathrm{C}$. After centrifugation, $\left(\mathrm{NH}_{4}\right)_{2} \mathrm{SO}_{4}$ was added to the supernatant to $80 \%$ saturation and the mixture was allowed to stand overnight at 4 . The precipitate obtained using $\left(\mathrm{NH}_{4}\right)_{2} \mathrm{SO}_{4}$ at 20 80\% saturation was subsequently dialyzed and freeze-dried to give a crude powder. This crude protein powder was dissolved in buffer A $(20 \mathrm{mM}$ Tris- $\mathrm{HCl}, 150 \mathrm{mM}$ $\mathrm{NaCl}, 1 \mathrm{mM}$ EDTA, pH7.0), applied to a column of Sephacryl S$100 \mathrm{HR}(2.6100 \mathrm{~cm})$, and eluted with the same buffer. Fractions with DNase activity were dialyzed, concentrated, and then loaded on a SynChropak AX weak anion-exhange column $(4.6 \times 250 \mathrm{~mm})$ in an Agilent 1100 HPLC system equilibrated with buffer B (20 mM Tis-HCl buffer, 1 mM EDTA, pH7.5). Four adsorbed peaks were eluted using a linear concentration $(0-0.5 \mathrm{M})$ gradient of $\mathrm{NaCl}$ in the same buffer. Fractions with DNase activity were concentrated and run on an Agilent GF-250 gel filtration column $(9.6 \times 250 \mathrm{~mm})$ in an Agilent 1100 HPLC system; buffer A was used for column equilibration and elution. The active fraction was collected, dialyzed, concentrated, and used as the purified enzyme for subsequent experiments.

In addition, reverse-HPLC was used to test CSDNase purity. $20 \mu \mathrm{l}$ of CSDNase solution was loaded on to an Agilent C18 column $(4.6 \times 250 \mathrm{~mm})$, which was eluted with a linear concentration $(10 \%-80 \%)$ gradient of acetonitrile in buffer B containing $0.05 \%$ trifluoroacetic acid at the flow rate of $1 \mathrm{ml} / \mathrm{min}$. Absorption at $210 \mathrm{~nm}$ was monitored during the elution. All procedures were carried out at $4^{\circ} \mathrm{C}$.

Assay for DNase activity Acid DNase activity was measured by using a hyperchromicity assay, essentially as described by Kunitz (Kunitz, 1950) and Ito et al. (Ito et al., 1984). Briefly, enzyme solutions $(10 \mu \mathrm{l})$ were added to a $1 \mathrm{ml}$ solution containing $40 \mu \mathrm{g}$ of Calf thymus DNA in reaction buffer $(50 \mathrm{mM}$ ammonium acetate, $1 \mathrm{mM}$ EDTA, pH5.5). After incubation $1 \mathrm{~h}$ at $55^{\circ} \mathrm{C}$, the reaction was stopped by adding $1.0 \mathrm{ml}$ of cold $5 \%$ perchloric acid to the mixture, which was stood for $10 \mathrm{~min}$ on ice, centrifuged at $10,000 \times g$ for $15 \mathrm{~min}$, and absorbance of the supernatant was measured at $260 \mathrm{~nm}$. Enzyme activities were measured at two different enzyme concentrations at least. One unit of enzyme activity is defined as the amount of enzyme producing an optical density change of $0.001 / \mathrm{min}$ under the above conditions (Baker et al., 1998).

Alternately, the agarose gel electrophoresis method was used. Samples $(5 \mu \mathrm{l})$ were added to a $45 \mu \mathrm{l}$ solution containing $1 \mu \mathrm{g}$ of different DNA substrates in reaction buffer. After incubation for $30 \mathrm{~min}$ at $55^{\circ} \mathrm{C}$, the integrities of the DNA substrates were monitored by gel electrophoresis of the DNA in $0.8 \%(\mathrm{w} / \mathrm{v})$ agarose gel and photographed under UV light (Kevin et al., 1998). In addition, DNase activity was monitored by plasmid nicking assay (Campbell and Jackson, 1980) using supercoiled plasmid pBR322 as a substrate.

SDS-PAGE and isoelectric focusing SDS-PAGE was conducted according to the method of Laemmli and Faver (Laemmli and Favre, 1973). After electrophoresis, gels were stained with Coomassie Brilliant Blue. The molecular weight of CSDNase was then determined by comparing its electrophoretic mobility with those of molecular weight marker proteins.

Isoelectric focusing (IEF) was performed as described by Sun et al. (Sun et al., 2003). The isoelectric point was determined in 5\% polyacrylamide gel containing $2 \%$ ampholine with a $\mathrm{pH}$ gradient from 3.5 to 9.5 .

CSDNase activity gel electrophoresis DNase activity by SDSPAGE was performed according to the methods of Blank et al. (Blank et al., 1982). A $12 \%$ polyacrylamide gel containing $0.1 \mathrm{mg} /$ $\mathrm{ml}$ of salmon testis DNA was used. Samples were electrophoresed without prior treatment with âmercaptoethanol or boiling. After electrophoresis, the gels were rinsed with two changes of $25 \%$ isopropanol in $50 \mathrm{mM}$ Tris- $\mathrm{HCl}(\mathrm{pH} \mathrm{7.0)}$, followed by three changes of reaction buffer. All rinses were for $30 \mathrm{~min}$ at room temperature in $250 \mathrm{ml}$ of the respective buffer. Rinsing was followed by $10 \mathrm{~h}$ of incubation at $55^{\circ} \mathrm{C}$ in reaction buffer. The incubated gels were then rinsed and stained with $0.5 \mu \mathrm{g} / \mathrm{ml}$ ethidium bromide for $30 \mathrm{~min}$, the dark band produced by CSDNase was observed under ultraviolet light.

Activity of CSDNase on different DNA substrates The activity of CSDNase on different DNA substrates was tested by the agarose gel electrophoresis. The purified CSDNase was incubated separately with different DNA substrates including ssDNA (Salmon testis DNA), dsDNA (calf thymus DNA, DNA), and supercoiled plasmid (pUC18, pBR322) in reaction buffer at $55^{\circ} \mathrm{C}$. 
Activity of CSDNase on RNA Purified yeast tRNA was used as a substrate, CSDNase was incubated with $200 \mu \mathrm{g}$ substrate in $150 \mu \mathrm{l}$ of $50 \mathrm{mM}$ ammonium acetate (pH 5.5) and then $350 \mu \mathrm{l}$ of ice-cold $3.4 \%$ perchloric acid was added to terminate the reaction. After standing on ice for $15 \mathrm{~min}$, the reaction mixture was centrifuged $(12,000 \times g \quad 15 \mathrm{~min})$ at $4^{\circ} \mathrm{C}$. The OD260 of the supernatant was measured after suitable dilution (Deshpande et al., 2001). Ribonuclease activity was taken as defined previously (Wang and $\mathrm{Ng}, 2001$ ).

Effect of $\mathrm{pH}$ and temperature on CSDNase activity and stability The relative rates of DNA hydrolysis by CSDNase at various $\mathrm{pH}$ values were determined by hyperchromicity assay. Ammonium acetate buffer $(50 \mathrm{mM})$ was used for $\mathrm{pH} 3-6$, potassium phosphate buffer $(50 \mathrm{mM})$ for $\mathrm{pH} 5-8$, and Tris- $\mathrm{HCl}$ buffer $(50 \mathrm{mM})$ for $\mathrm{pH} 7-11$. Enzyme stabilities were determined after pre-incubating CSDNase sample for $24 \mathrm{~h}$ at various $\mathrm{pH}$ levels without substrate.

The optimum temperature for the CSDNase activity was determined by hyperchromicity assay over the range $4-90^{\circ} \mathrm{C}$. Thermal stability was determined by assaying the residual CSDNase activity after incubating CSDNase sample for $15 \mathrm{~min}$ at different temperature without substrate.

Activation of CSDNase by metal ions The effect of metal ions on the activity of CSDNase was determined by hyperchromicity assay, and agarose gel electrophoresis was also used for detecting the effect of EDTA on the activity of CSDNase. In the test, the effect of divalent metal ions $\left(\mathrm{MgCl}_{2}, \mathrm{MnCl}_{2}, \mathrm{ZnCl}_{2}, \mathrm{CaCl}_{2}\right)$, univalent metal ions $(\mathrm{NaCl}, \mathrm{KCl})$ and EDTA were examined on CSDNase activity.

Terminal phosphate position of the products generated by CSDNase digestion The position of the terminal phosphate in the digestion products formed by CSDNase was determined using the method of Ikeda and Takata (2002). Calf thymus DNA was digested with CSDNase in reaction buffer at $55^{\circ} \mathrm{C}$ until approximately $25 \%$ of the DNA became acid-soluble. The reaction was stopped by heating at $80^{\circ} \mathrm{C}$ for $20 \mathrm{~min}$. As a control, DNA cut by DNase I was prepared in the same manner, except that the reaction proceeded at $37^{\circ} \mathrm{C}$ in buffer consisting of $20 \mathrm{mM}$ Tris- $\mathrm{HCl}$ $(\mathrm{pH} 7.5)$ and $5 \mathrm{mM} \mathrm{MgCl}_{2}$. To remove the terminal phosphate group, the DNA was treated with bacterial alkaline phosphatase at $37^{\circ} \mathrm{C}$ for $10 \mathrm{~min}$ before being reacted with phosphodiesterase.

Phosophodiesterase I from Crotalus adamanteu venom is a 3'to-5' exonuclease, and bovine spleen phosphodiesterase II is a 5'-to-
3' exonuclease. A limited digest (approx. 25\% acid-soluble) of calf thymus DNA by CSDNase was used as substrate for phosophodiesterases I and II.

\section{Results}

Purification of CSDNase A new DNase that acted at an acidic $\mathrm{pH}$ without divalent metal ions, was extracted from $C$. sinensis and designated CSDNase. The enzyme was purified by $\left(\mathrm{NH}_{4}\right)_{2} \mathrm{SO}_{4}$ precipitation, gel filtration of Sephacryl S-100 HR, weak anion-exchange HPLC, and gel filtration HPLC. The yields and degrees of purification of the CSDNase present in the $C$. sinensis and the activity on calf thymus DNA are summarized in Table 1, Chromatographic elution profiles are shown in Fig. 1. From $20 \mathrm{~g}$ of $C$. sinensis mycelium $(1 \mathrm{~L}$ culture medium of $C$. sinensis) approximately $0.5 \mathrm{mg}$ of the purified CSDNase was obtained for analysis; enzyme purification was $c a .500$ fold.

A single peak was observed when reverse-phase HPLC was used to test the purity of CSDNase (Fig. 2A). As shown in Figs. 2B, and 2D, the CSDNase sample obtained was also identified to be pure by SDS-PAGE and IEF.

Characterization of CSDNase CSDNase was found to be a single-chain polypeptide, because it produced a single band by PAGE and SDS-PAGE (Fig. 2B 2C). The molecular weight of CSDNase in the native state was determined to be $36 \mathrm{kDa}$ by gel-filtration HPLC using an Agilent GF250 column (Fig. 1C.). The purified CSDNase had an apparent molecular mass of $34 \mathrm{kDa}$ by SDS-PAGE and by SDS activity gels using ethidium bromide (Fig. 2B). The difference between the molecular mass determined by SDS-PAGE and that determined by gel filtration may be due to a non-globular native protein shape. IEF showed that CSDNase had a $\mathrm{pI}$ of 7.05 (Fig. 2D).

Enzyme substrate specificity As shown in Fig. 3, CSDNase acted on both dsDNA and ssDNA, but the enzyme attacked dsDNA at a 1.5 times higher rate than ssDNA (Fig. 4C). CSDNase also acted on DNA supercoiled plasmid dsDNA without selectivity (Fig. 3), but showed no RNase activity on yeast tRNA. These results indicate that the isolated CSDNase is an endonuclease that cleaves DNA as substrate.

Table 1. Purification of CSDNase

\begin{tabular}{lcccc}
\hline \multicolumn{1}{c}{ Fraction } & $\begin{array}{c}\text { Activity } \\
\text { (units) }\end{array}$ & $\begin{array}{c}\text { Protein } \\
(\mathrm{mg})\end{array}$ & $\begin{array}{c}\text { Specific activity } \\
\text { (units/mg) }\end{array}$ & $\begin{array}{c}\text { Yield } \\
(\%)\end{array}$ \\
\hline Crude extract & 2026.2 & 921 & 2.2 & 100 \\
$\left(\mathrm{NH}_{4}\right)_{2} \mathrm{SO}_{4}$ precipitation & 1784.8 & 401.2 & 4.4 & 88.1 \\
Sephacryl S-100 HR & 1345.2 & 35.2 & 38.2 & 66.4 \\
Weak anion-exchange HPLC & 642.6 & 2.4 & 267.8 & 31.7 \\
Gel filtration HPLC & 598.6 & 0.5 & 997.2 & 24.6 \\
\hline
\end{tabular}

Purification was initiated from $20 \mathrm{~g}$ dry cultured mycelia of Cordyceps sinensis. 

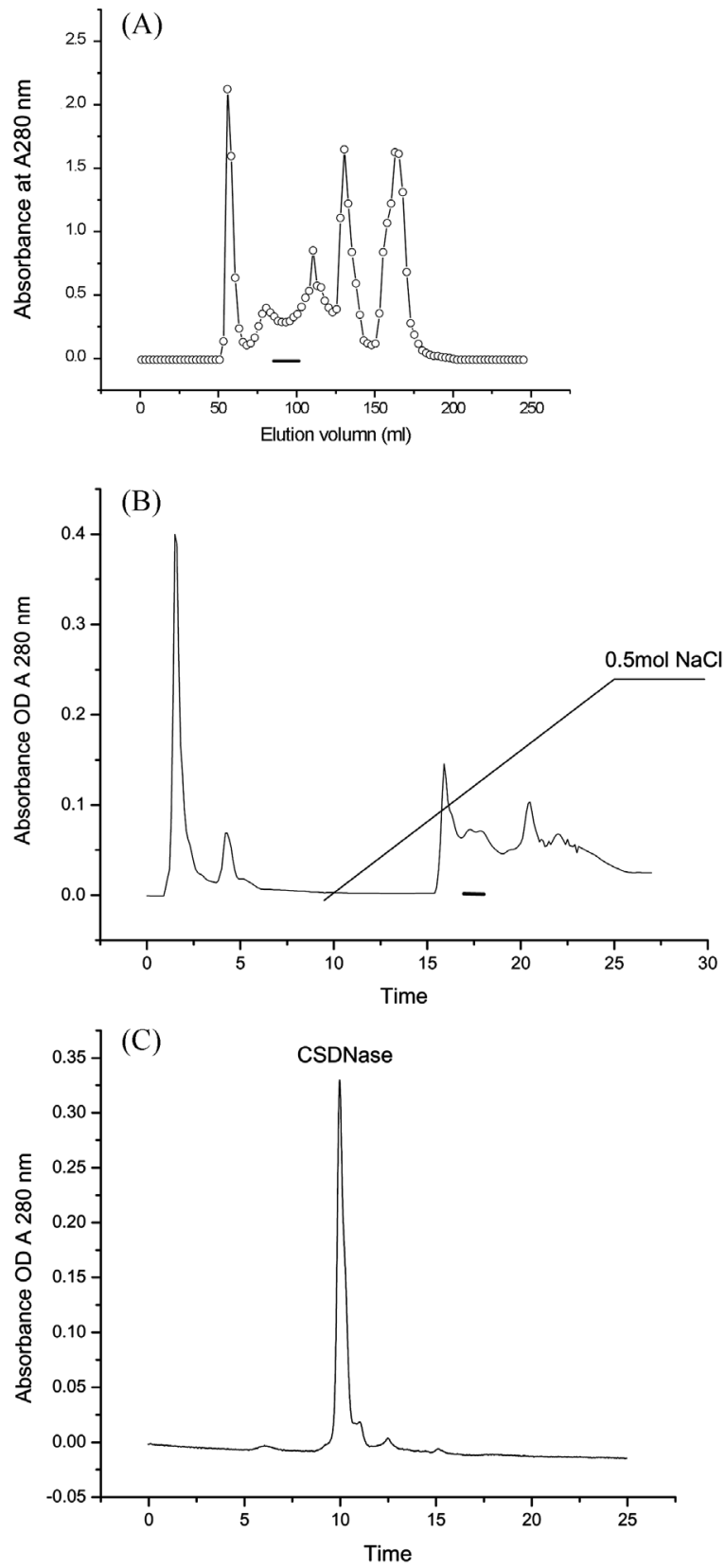

Fig. 1. (A) Gel filtration chromatography on Sephacryl S-100 HR. Column dimensions: $2.6 \times 100 \mathrm{~cm}$. Buffer: $20 \mathrm{mM}$ Tris- $\mathrm{HCl}$, $150 \mathrm{mM} \mathrm{NaCl}, \mathrm{pH} 7.0$ (-DNase activity fraction). (B) Weak anion-exchange HPLC in Agilent 1100 HPLC system. Column: SynChropak AX300 weak anion-exchange column $(4.6 \times 250$ $\mathrm{mm})$. Sample: DNase activity fractions on Sephacryl S-100 HR. Starting buffer: $20 \mathrm{mM}$ Tris- $\mathrm{HCl}$ (pH 7.5). Flow rate: $1.2 \mathrm{ml} / \mathrm{min}$. Column temperature: $4^{\circ} \mathrm{C}$. The column was eluted by a linear concentration $(0-0.5 \mathrm{M})$ gradient of $\mathrm{NaCl}$ in the starting buffer (DNase activity fraction). (C) Gel filtration HPLC in Agilent 1100 HPLC system. Column: Agilent Zorbax GF-250 column $(9.6 \times 250 \mathrm{~mm})$. Sample: DNase activity fractions on Weak anion-exchange HPLC. Buffer: $20 \mathrm{mM}$ Tris- $\mathrm{HCl}, 150 \mathrm{mM} \mathrm{NaCl}$ (pH7.0). Flow rate, $1 \mathrm{ml} / \mathrm{min}$; Column temperature, $4^{\circ} \mathrm{C}$.
(A)
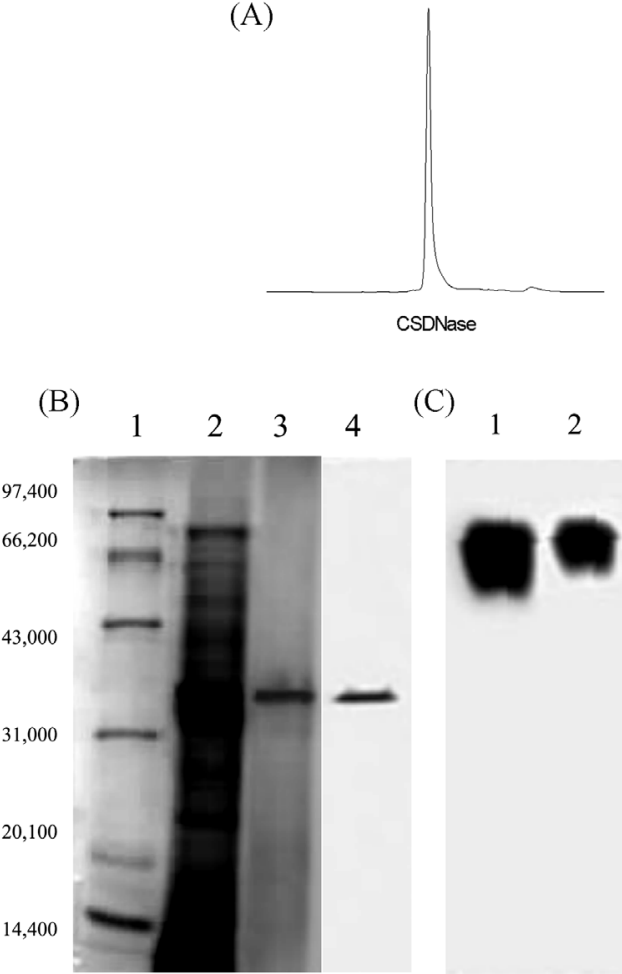

C) 12

(D)

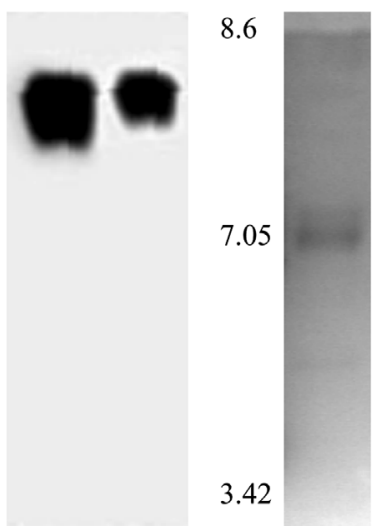

Fig. 2. (A) Reverse-HPLC of CSDNase (B) SDS-PAGE. Lane 1, protein molecular weight markers; Lane 2, Crude protein of $C$. sinensis; Lane 3, Purified CSDNase; Lane 4, Activity SDS-PAGE of CSDNase. (C) Activity-PAGE; Lane 1, Porcine spleen acid DNase; Lane 2, CSDNase (D) Isoelectric focusing of CSDNase.

Enzymatic properties of CSDNase The optimum $\mathrm{pH}$ of CSDNase was pH 5.5 in $50 \mathrm{mM}$ ammonium acetate buffer. At pHs of 4.5 and 7 the enzyme exhibited only a half of its maximum activity (Fig. 4A). In addition, the enzyme activity was unaffected after being incubated at $\mathrm{pH} 4-7$ for $24 \mathrm{~h}$ in $37^{\circ} \mathrm{C}$.

The enzyme was active at $20^{\circ} \mathrm{C}$, and its activity increased as the incubation temperature increased up to an optimum temperature of $55^{\circ} \mathrm{C}$ (Fig. 4B). The enzyme was stable after incubation for $15 \mathrm{~min}$ at $65^{\circ} \mathrm{C}$, but completely lost its activity after $15 \mathrm{~min}$ at $80^{\circ} \mathrm{C}$.

The activity of CSDNase was not dependent on divalent or univalent cations, but was inhibited by high concentrations of cations; $\mathrm{MgCl}_{2}$ above $150 \mathrm{mM}, \mathrm{MnCl}_{2}$ above $200 \mathrm{mM}, \mathrm{ZnCl}_{2}$ above $150 \mathrm{mM}, \mathrm{CaCl}_{2}$ above $200 \mathrm{mM}, \mathrm{NaCl}$ above $300 \mathrm{mM}$, and $\mathrm{KCl}$ above $300 \mathrm{mM}$, and these conditions completely inhibited its activity. EDTA did not inhibit the activity of CSDNase even at $10 \mathrm{mM}$ (Table 2), indicating that CSDNase does not require divalent cations for activity, and that it could be inhibited by high cation concentrations.

Mode of action of CSDNase The hydrolytic effect of CSDNase on dsDNA was determined by examining it effect 
(A)

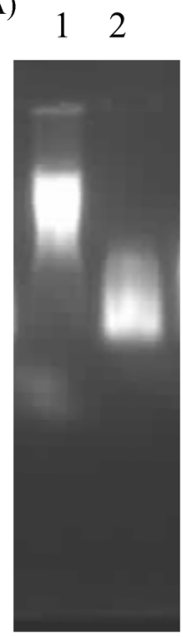

(B)

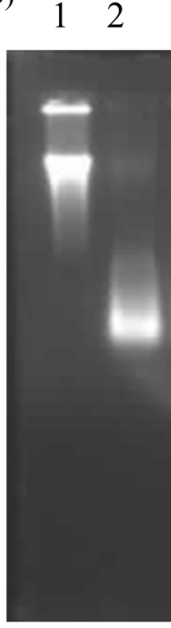

(C)

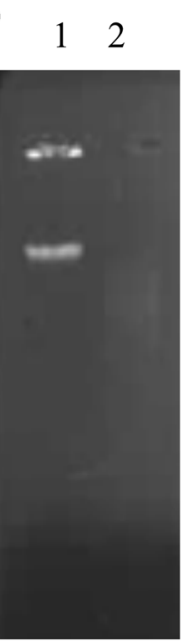

(D)

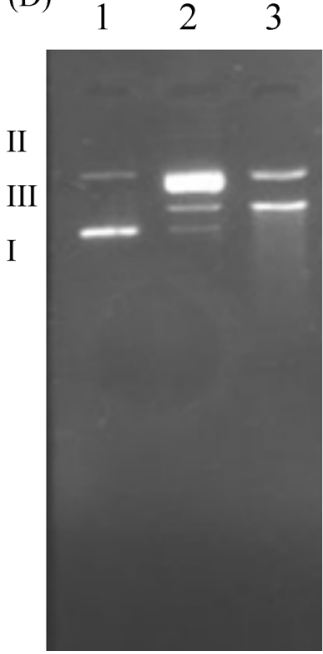

(E)

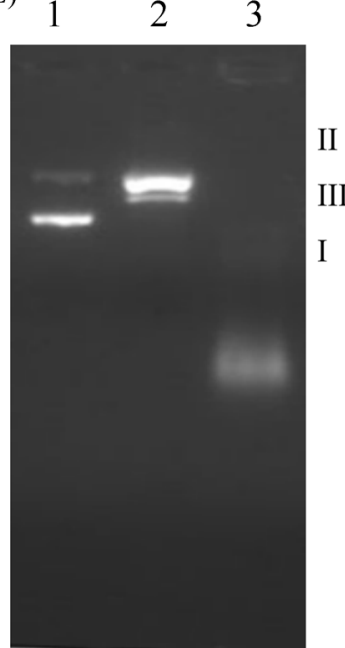

Fig. 3. (A) Salmon testis DNA. Lane 1, no enzyme; Lane 2, with 0.05 unit CSDNase. (B) Calf thymus DNA; Lane 1, no enzyme; Lane 2: with 0.05 unit CSDNase. (C) $\lambda$ DNA. Lane 1, no enzyme; Lane 2, with 0.05 unit CSDNase. (D) pBR322 plasmid DNA. Lane 1, no enzyme; Lane 2, with 0.05 unit CSDNase Lane 3, with 0.2 unit CSDNase. (E) pUC18 plasmid DNA. Lane 1, no enzyme; Lane 2, with 0.1 unit CSDNase Lane 3 , with 0.4 unit CSDNase.

on plasmid DNA in the absence of bivalent metal ions at $\mathrm{pH}$ 5.5 and $37^{\circ} \mathrm{C}$. Supercoiled plasmid DNA (form I) was digested with a small mount of CSDNase, and the products were subjected to agarose gel electrophoresis. The initial products generated by the enzyme initially were nicked plasmid DNAs (form II). Linear DNAs (form III) were then observed with an increase in nicked open circle DNA. Finally, all of the plasmid DNA was hydrolysed by the CSDNase (Fig. 3D 3E). Moreover, this hydrolysis pattern did not change when the DNA plasmid was changed. These results indicate that C.sinensis CSDNase is an endonuclease that causes double-strand breaks in DNA substrates.
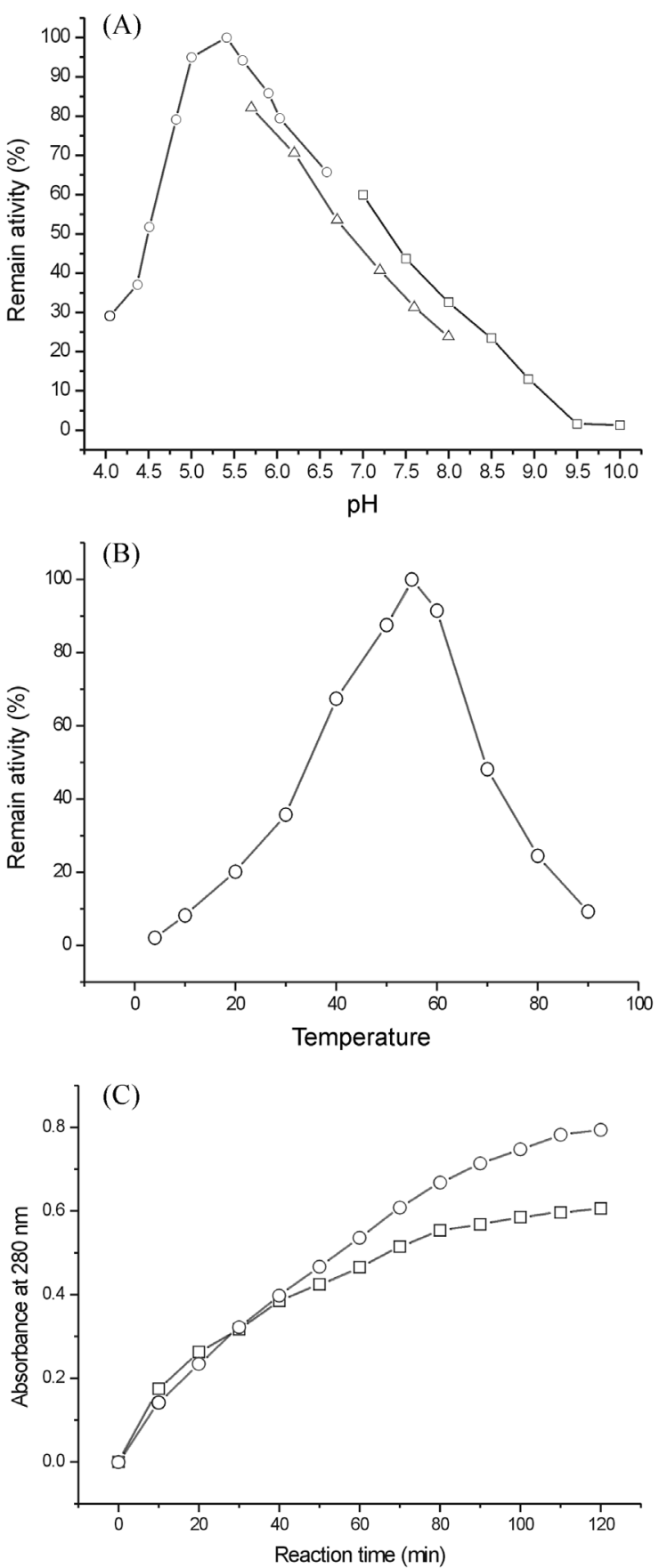

Fig. 4. (A) Effect of $\mathrm{pH}$ on the activity of CSDNase on Calf thymus DNA at $55^{\circ} \mathrm{C}$ ( $\square$ Tris- $\mathrm{HCl}$ Buffer, $\bigcirc$ ammonium acetate buffer, $\triangle$ potassium phosphate buffer). (B) Effect of temperature on the activity of CSDNase on calf thymus DNA, in $50 \mathrm{mM}$ ammonium acetate buffer ( $\mathrm{pH}$ 5.5). (C) Hydrolysis of ssDNA and dsDNA by CSDNase for various times ( $\square$ ssDNA, $\bigcirc$ dsDNA).

Terminal phosphates of the hydrolysis products produced by CSDNase The hydrolysis products formed by CSDNase were found to be readily cleaved by phosphodiesterase II, but not by phosphodiesterase I. After alkaline phosphatase treatment, the DNA products were readily cleaved by 
Table 2. Effect of different concentrations of cations (at $55^{\circ} \mathrm{C}$ and $\mathrm{pH} 5.5$ ) on the activity of CSDNase

\begin{tabular}{|c|c|c|c|c|}
\hline \multirow{2}{*}{ Salt } & \multicolumn{3}{|c|}{ Relative activity (\%) } & \multirow{2}{*}{$\begin{array}{l}\text { Inhibiting } \\
\text { concentration } \\
(\mathrm{mM})\end{array}$} \\
\hline & $1 \mathrm{mM}$ & $10 \mathrm{mM}$ & $100 \mathrm{mM}$ & \\
\hline Control & 100 & 100 & 100 & \\
\hline $\mathrm{NaCl}$ & 105 & 106 & 71 & 300 \\
\hline $\mathrm{KCl}$ & 102 & 101 & 75 & 300 \\
\hline $\mathrm{MnCl}_{2}$ & 103 & 92 & 38 & 200 \\
\hline $\mathrm{CaCl}_{2}$ & 105 & 90 & 36 & 200 \\
\hline $\mathrm{MgCl}_{2}$ & 100 & 90 & 30 & 150 \\
\hline $\mathrm{ZnCl}_{2}$ & 109 & 93 & 32 & 150 \\
\hline EDTA & 98 & 85 & 25 & 125 \\
\hline
\end{tabular}

phosphodiesterase I. In contrast, DNA products digested with DNase I (which produces 3'-OH and 5'-phosphate termini) were readily cleaved by phosphodiesterase I, but not by phosphodiesterase II. This finding indicates that the oligonucleotides produced had a phosphate group at the 3'termini and a hydroxy group at the 5'-termini, which is characteristic of acid DNases (Schomburg and Salzmann, 1991).

\section{Discussion}

A new acid DNase, designated CSDNase, was isolated from the cultured mycelia of Cordyceps sinensis. CSDNase was purified by $\left(\mathrm{NH}_{4}\right)_{2} \mathrm{SO}_{4}$ precipitation and a series of chromatographic separations. The protein was found to be single-chained with an apparent molecular mass of $34 \mathrm{kDa}$, and a $\mathrm{p} I$ value of 7.05. CSDNase was found to act on both dsDNA and ssDNA as a deoxyribonuclease, but to act preferentially on dsDNA. CSDNase with a $\mathrm{pH}$ optimum at $c a$. 5.5 , and an optimum temperature of $55^{\circ} \mathrm{C}$. It enzyme activity was found to be divalent metal ion independent, and EDTA did not inhibit its enzyme activity. The oligonucleotides produced by CSDNase digestion had 3'-phosphate and 5'-OH end groups.

In this experiment, the fungal origin of this DNase activity was confirmed by the finding that no DNase activity was found in the initial culture medium. Moreover, because almost no DNase activity could be detected in the culture medium, and the acid DNase activity of mycelium was no higher when mycelia were cultured after 96h, we can conclude that CSDNase is an endocellular enzyme.

Although acid DNase was first studied biochemically in the 1960's (Bernardi et al., 1965), their structures have not been elucidated and there is some debate concerning the structure of DNase II. Several reports suggest that procine spleen DNase II is a heterodimeric protein, consisting of a $1: 1$ complex of the $\alpha$ and $\beta$ polypeptide chains with molecular weights of 35 and $10 \mathrm{kDa}$, respectively (Liao, 1985; Liao et al., 1989). Another DNase II from the human liver was found to consist of three non-identical subunits (Taskeshita et al., 1998). Other reports suggest that DNase II enzymes from other sources consists of a single polypeptide chain with different molecular weights of approximately $25-40 \mathrm{kDa}$; e.g. $36-38 \mathrm{kDa}$ from rat liver (Dulaney and Touster, 1972); $38 \mathrm{kDa}$ from hog spleen (Bernardi, 1971); $32 \mathrm{kDa}$ from human urine (Yasuda et al., 1992); $38 \mathrm{kDa}$ from human gastric mucosa and cervix (Yamanaka et al., 1974); $26 \mathrm{kDa}$ from bovine liver (Lesca, 1975); $45 \mathrm{kDa}$ from human lymphoblasts (Harosh et al., 1991); Euglena acid DNase from Euglena gracilis SMZK (Ikeda and Takata, 2002), and $35 \mathrm{kDa}$ enzyme with a DNase I-like structure exhibiting acidic DNase II-like activity from human (Appierto et al., 1997). The molecular mass of CSDNase was found to be $c a .34 \mathrm{kDa}$, which is in the reported range for a single-chained acid DNase. The isoelectric point of CSDNase is 7.05, which is similar to other acid DNases, e.g., DNase II from porcine spleen ( $\mathrm{p}$ 7 7.7), liver (pI 7.5), and gastric mucosa (pI 7.3) (Liao et al., 1989).

The catalytic properties of CSDNase are essentially the same as those of all other well described acid DNases, e.g., Euglena acid DNase (Ikeda and Takata, 2002), rat liver lysosomes acid DNase (Dulaney and Touster, 1972), porcine spleen acid DNase (Liao, 1985; Liao et al., 1989), human urine acid DNase (Yasuda et al., 1992), and human gastric mucosa and cervix uteri acid DNase (Yamanaka et al., 1974). CSDNase is an endonuclease, which is activated in low $\mathrm{pH}$ conditions, does not require divalent metal ions, is inhibited by high concentrations of cations, and is active against single and double stranded DNA. Like other acid DNases, CSDNase also acts preferentially on dsDNA and generates 3'-phosphate and 5'-OH termini. These findings indicate that CSDNase is a DNase II.

However, the activity of CSDNase differs slightly from other acid DNases. CSDNase has less preference for dsDNA than some other acid DNases. CSDNase hydrolyzes dsDNA about 1.5 times faster than ssDNA, but most acid DNases hydrolyze dsDNA about 3-4 times faster than ssDNA (Dulaney and Touster, 1972; Liao, 1985; Yasuda et al., 1992; Ikeda and Takata, 2002), and the acid DNase from human gastric mucosa and cervix uteri hydrolyze dsDNA about 1020 times faster than ssDNA (Yamanaka et al., 1974). Moreover, CSDNase is inhibited only at high ion concentrations in the reaction buffer, and lost its activity at concentrations higher than 150-300 mM (Table 2), whereas most acid DNases lose their activities at ion concentrations >50mM (Dulaney and Touster, 1972; Yamanaka et al., 1974; Liao, 1985; Yasuda et al., 1992; Ikeda and Takata, 2002). These differences may be the reason for the diversity of the individual enzyme's action.

It is interesting to note that CSDNase showed nick activity on supercoiled plasmid dsDNA. As shown in Fig. 3D and 3E, the enzyme not only cleaved supercoiled plasmid DNA (form I) without bivalent metal ions at $\mathrm{pH} 5.5$ in $37^{\circ} \mathrm{C}$, but also produced nicked supercoiled plasmid DNA (form II) on the first time. Early reports characterized acid DNase as an 
enzyme that cleaves DNA in a mechanistically different manner from the DNA nicking activity of pancreatic DNase I. Using the same technique, scission by the DNase II isolated from rat small intestinal mucosa was shown to consist mainly of double-strand breaks (Anai et al., 1983), and a recent report showed that an acid DNase from Euglena gracilis also did not have nick activity on supercoiled plasmid DNA and could only break supercoiled plasmid DNA (Ikeda and Takata, 2002). But most recent reports have suggested that some acid DNases possess nicking activity (Harosh et al., 1991; Baker et al., 1998), which cleaves supercoiled plasmid DNA like DNase I, which nicks supercoiled plasmid DNA in the present of divalent cations. The reason for this different acid DNase activity on supercoiled plasmid dsDNA has not been clarified. We found that CSDNase has nick activity on supercoiled plasmid DNA, which indicates that CSDNase belongs to the subgroup of the acid DNase family with nicking activity.

The functions of CSDNase are unclear, but considering the fact that its activity is primarily expressed during fungal mycelium growth (data not showed) and it is an endocellular enzyme, one might conjecture that CSDNase may be involved in the meiosis of the fungal mycelium. Further works are in progress to determine the amino acid sequence and the functions of this enzyme.

Acknowledgments The authors wish to thank Dr. Hui Sun and Mr. ChenGuang Zhao for their technical assistance. The authors express their thanks to Dr. Feng Liu for his excellent secretarial assistance.

\section{References}

Anai, M., Muta, A. and Umeno, M. (1983) Purification and properties of an acid deoxyribonuclease from small intestinal mucosa. J. Biochem. 94, 339-344.

Appierto, V., Bardella, L., Vijayasarathy, C., Avadhani, N., Sgaramella, V. and Biunno, I. (1997) Functional characterization of human DNase-like protein encoded by a gene positioned in Xq28. Gene 188, 119-122.

Baker, K.P., Baron, W.F., Henzel, W.J. and Spencer, S.A. (1998) Molecular cloning and characterization of human and murine DNase II. Gene 215, 281-289.

Barry, M. A. and Eastman, A. (1993) Identification of deoxyribonuclease II as an endonuclease involved in apoptosis. Arch. Biochem. Biophys. 300, 440-450.

Bernardi, G. (1971) Spleen acid deoxyribonuclease. in The Enzymes, Boyer, P. D. (ed.), pp. 271-287, Academic Press, New York, USA.

Bernardi, G., Appella, E. and Zito, R. (1965) Studies on acid deoxyribonuclease. III. Physical and chemical properties of hog spleen acid deoxyribonuclease. Biochemisty 4, 1725-1729.

Blank, A., Sugiyama, R. H. and Dekker, C. A. (1982) Activity staining of nucleolytic enzymes after sodium dodecyl sulfatepolyacrylamide gel electrophoresis: use of aqueous isopropanol to remove detergent from gels. Anal. Biochem. 120, 267-275.

Campbell, V. W. and Jackson, D. A. (1980) The effect of divalent cations on the mode of action of DNase I: The initial reaction products produced from covalently closed circular DNA. $J$. Biol. Chem. 255, 3726-3735.

Catcheside, D.G. and Holmes, B. (1947) The action of enzymes on chromosomes. Symp. Soc. Exp. Biol. 1,225-231.

Chen, L.Y., Ho, H. C., Tsai, Y. C. and Liao, T. H. (1993) Deoxyribonuclease of Syncephalastrum racemosum enzymatic properties and molecular structure. Arch. Biochem. Biophys. 303, 51-56.

Conneely, A.M., Campbell. G.R., and Winder, F.G. (1976) Purification of a deoxyribonuclease from Aspergillus nidulans. Biochem. Soc. Trans. 4, 879-881.

Cunningham, L. and Laskowski, M. (1953) Presence of two different desoxyribonucleodepolymerases in veal kidney. Biochem. Biophys. Acta. 11, 590-591.

Deshpande, R. A., Kumar, A. R., Khan, M. I. and Shankar, V. (2001) Ribonuclease rs from Rhizopus stolonifer: lowering of optimum temperature in the presence of urea. Biochim. Biophys. Acta 1545, 13-19.

Dulaney, J. T. and Touster, O. (1972) Isolation of deoxyribonuclease II of rat liver lysosomes. J. Biol. Chem. 247, 1424-1432.

Harosh, I., Binninger, D. M., Harris, P. V., Mezzina, M. and Boyd, J. B. (1991) Mechanism of action of deoxyribonuclease II from human lymphoblasts. Eur. J. Biochem. 202, 479-484.

Hsu, T. H., Shiao, L. H., Hsieh, C. Y. and Chang, D. M. (2002) A comparison of the chemical composition and bioactive ingredients of the Chinese medicinal mushroom DongChongXiaCao, its counterfeit and mimic, and fermented mycelium of Cordyceps sinensis. Food Chemistry 78, 463-469.

Ikeda, S. and Takata N. (2002) Deoxyribonuclease II purified from Euglena gracilis SM-ZK, a chloroplast-lacking mutant: comparison with porcine with porcine spleen deoxyribonuclease II. Comp. Biochem. and physiol. 131, 519525.

Ito, K., Minamiura, N. and Yamamoto, T. (1984) Human Urine DNase I: Immunological identity with human pancreatic DNase I, and enzymic and proteochemical properties of the enzyme. $J$. Biochem. 95, 1399-1406.

Kevin, P. B., Will, F. B., William, J. H. and Steven A. S. (1998) Molecular cloning and characterization of human and murine DNase II. Gene 215, 281-289.

Kitamura, A., Kouroku, Y., Onoue, M., Kimura, S., Takenouchi, M. and Sakaguchi, K. (1997) A new meiotic endonuclease from Coprinus meiocytes. Biochim. Biophys. Acta 1342, 205216.

Kunitz, M. (1950) Crystalline desoxyribonuclease: Isolation and general properties; a spectrophotometric method for the measurement of desoxyribonuclease activity. J. Gen. Physiol. 33, 349-362.

Laemmli, U. K. and Favre, M. (1973) Gel electrophoresis of protein. J. Mol. Biol. 80, 575-599.

Lesca, P. (1975) Protein inhibitor of acid deoxyribonucleases; Improved purification procedure and properties. J. Biol. Chem. 254, 116-123.

Liao, T. H. (1985) The subunit structure and active site sequence of porcine spleen deoxyribonuclease. J. Biol. Chem. 260, 10708-10713.

Liao, T. H., Liao, W. C., Chang, H. C. and Lu, K. S. (1989) Deoxyribonuclease II purified from the isolated lysosomes of 
porcine spleen and from porcine liver homogenates. Comparison with deoxyribonuclease II purified from porcine spleen homogenates. Biochim. Biophys. Acta 1007, 15-22.

Lu, B. C., Wong, W., Fannibg, L. and Sakaguchi, K. (1988) Purification and characterization of an endonuclease from fruiting caps of basidiomycete Coprinus cinereus. Eur. J. Biochem. 174(4), 725-732.

Moore, S. (1981) Pancreatic DNase. in The Enzymes, Vol. 14, Boyer, P. D. (ed.), pp. 281-296, Academic Press, New York, USA.

Schomburg, D. and Salzmann, M. 1991. DNase II. in Enzyme Handbook, vol. 3. Class 3: Hydrolases, pp. 1-6, Springer, Heidelberg, Denmark.

SteinKraus, D.C. and Whitfield, J.B. (1994) Chinese caterpillar fungus and world record runners. American Entomologist 40, 235 .

Sun, H., Zhao, C. G., Tong, X. and Qi, Y. P. (2003) A lectin with mycelia differentiation and antiphytovirus activities from the edible mushroom Agrocybe aegerita. J. Biochem. Mol. Biol 36, 214-222.

Taskeshita, H., Yasuda, T., Iida, R., Nakajima, T., Hosomi, O., Nakashima, Y., Mori, S., Nomoto, H. and Kishi, K. (1998)
Identification of the three non-identical subunits constituting human deoxyribonuclease II. FEBS lett. 440, 239-242.

Wang, H. and $\mathrm{Ng}, \mathrm{T}$. B. (2001) Isolation of a novel deoxyribonuclease with antifungal activity from Asparagus officinalis seeds. Biochem. Biophys. Res. Commun. 289, 120124.

Yamanaka, M., Tsubota, Y., Anai, M., Ishimatsu, K., Okumura, M., Katsuki, S. and Takagi, Y. (1974) Purification and properties nof acid deoxyribonuclease of human gastric mucosa and cervix uteri. J. Biol. Chem. 249, 3884-3889.

Yasuda, T., Nadano, D., Awazu, S. and Kishi, K. (1992) Human urine deoxyribonuclease II (DNase II) isoenzymes: a novel immunoaffinity purification, biochemical multiplicity, genetic heterogeneity and broad distribution among tissues and body fluids. Biochim. Biophys. Acta 1119, 185-193.

Zhu, J. S., Halpern, G. M. and Jones, K. (1998a) The scientific rediscovery of an ancient Chinese herbal medicine: Cordyceps sinensis: Part I. J. Altern Complement Med. 4, 289-303.

Zhu, J. S., Halpern, G. M. and Jones, K. (1998b) The scientific rediscovery of an ancient Chinese herbal medicine: Cordyceps sinensis: Part II. J. Altern Complement Med. 4, 429-457. 